\title{
Beware the middle-aged migraine: internal carotid artery dissection mimicking migraine in the emergency department
}

\author{
Austin Donnelly, Brendan Sinnott, Ryan Boyle, Ian Rennie
}

Emergency Department, Royal Victoria Hospital, Belfast, UK

\section{Correspondence to \\ Dr Austin Donnelly,} adonnelly32@qub.ac.uk

Accepted 13 November 2017

CrossMark

To cite: Donnelly $A$, Sinnott B, Boyle R, et al. BMJ Case Rep Published Online First: [please include Day Month Year]. doi:10.1136/ bcr-2017-221774

\section{DESCRIPTION}

A 53-year-old woman presented to the emergency department (ED) with a 3-day history of gradual onset left-sided headache localised behind the left eye. This was associated with visual disturbance in the left eye described as 'zig-zag lines'.

She had never suffered from headache before and her only significant medical history was of hysterectomy and subsequent provoked pulmonary embolus. She was not taking any regular medication.

Initial assessment was completed by an Foundation Year 2 doctor (FY2) in ED. There was no evidence of focal neurological deficit. A diagnosis of migraine with aura was reached and the patient was discharged home with a short course of non-steroidal anti-inflammatories and paracetamol. She was advised to return to the ED if her symptoms failed to improve or in the event of new symptoms developing.

She returned the following day. The patient was again assessed by an FY2 in ED. The description of her headache had not changed. However, on this occasion, she had developed ptosis, meiosis and on further examination anhydrosis (Horner's syndrome). Her case was discussed with a senior ED clinician who advised urgent neuroimaging was required.

Non-contrast CT brain was normal. However, CT angiography revealed an extensive left internal carotid artery (ICA) dissection (figure 1) with associated pseudoaneurysm (figure 2).

The finding of left ICA dissection necessitates urgent anticoagulation due to the strong association between arterial dissection and thromboembolic disease including stroke. ${ }^{12}$

Other stroke risk factors were assessed including blood pressure, lipid profile and fasting glucose. She started on both lipid-lowering and blood pressure medication as a result. The patient was also advised about modifiable lifestyle factors such as diet and exercise.

Her headache continued to be managed by using simple analgaesia.

Ongoing follow-up was arranged at the Stroke Outpatient Clinic. At the time of last review, the patient was asymptomatic. Further follow-up imaging is awaited at time of writing this case report.

In retrospect, it is clear that the patient's first presentation at the ED did not meet criteria for migraine with aura. As per the International

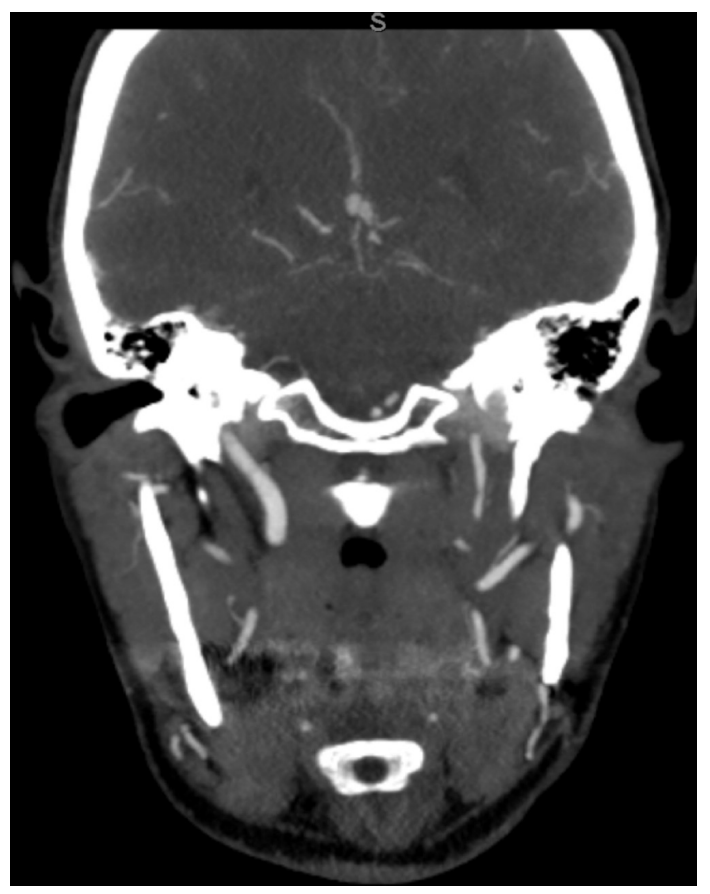

Figure 1 Coronal view of $\mathrm{CT}$ angiography showing significant luminal narrowing of the left ICA from the level of C2 throughout the left carotid canal with a stringlike and tortuous appearance, likely due to dissection.

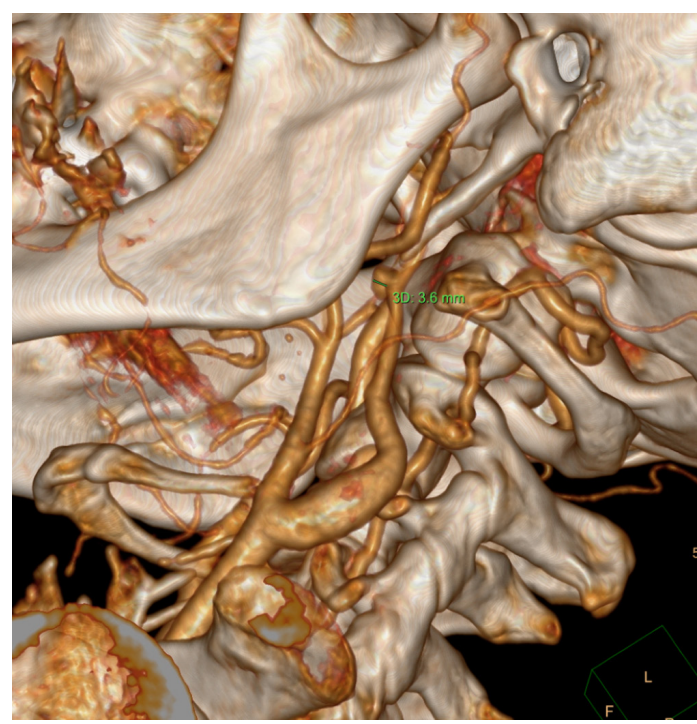

Figure 2 Reconstructed CT angiography showing the pre-petrous segment of the ICA with luminal narrowing and a small pseudoaneurysm measuring $4 \mathrm{~mm} \times 6 \mathrm{~mm}$. 
Classification of headache Disorders, the following diagnostic requirements were not met:

1. Two separate attacks were not reported.

2. Full reversibility of aura symptoms had not been demonstrated.

Somewhat confusingly, however, "Headache or facial or neck pain attributed to cervical arterial dissection is usually unilateral (ipsilateral to the dissected artery), severe and persistent (for a mean of 4 days). However, it has no constant specific pattern and it can sometimes be very misleading, mimicking other headaches

\section{Learning points}

- It is important to seek specialist input from a neurologist in cases of headache that do not meet diagnostic criteria for primary headache.

- 'Safety-netting' advice in the emergency department is of importance.

- There is an urgent need for anticoagulation in patients diagnosed with carotid artery dissection. such as 1. Migraine, 3.1 Cluster headache or 4.4 Primary thunderclap headache". ${ }^{3}$

Contributors The patient was seen in the emergency department upon representation by $A D$. When final diagnosis was made, the case was discussed by $B S$ and $A D$ and a decision to write the case up was made. BMJ Case Reports journal was identified as an appropriate publication. The case was written up based on the BMJ Case Reports model by AD and proof-read by BS. AD is acting as corresponding author. RB was heavily involved in helping to address comments raised during the peer review process. IR is the reporting radiologist.

Competing interests None declared.

Patient consent Obtained.

Provenance and peer review Not commissioned; externally peer reviewed.

(C) BMJ Publishing Group Ltd (unless otherwise stated in the text of the article) 2017. All rights reserved. No commercial use is permitted unless otherwise expressly granted.

\section{REFERENCES}

1 Redekop GJ. Extracranial carotid and vertebral artery dissection: a review. Can J Neurol Sci 2008;35:146-52.

2 Schievink WI. The treatment of spontaneous carotid and vertebral artery dissections. Curr Opin Cardiol 2000;15:316-21.

3. International Headache Society. International classification of headache disorders (beta version) [Internet]. 3rd edn. Sage Publications Ltd, 2016. https:// www.ichd-3.org/6-headache-attributed-to-cranial-or-cervical-vascular-disorder/ (accessed 25 Sep 2017).

Copyright 2017 BMJ Publishing Group. All rights reserved. For permission to reuse any of this content visit

http://group.bmj.com/group/rights-licensing/permissions.

BMJ Case Report Fellows may re-use this article for personal use and teaching without any further permission.

Become a Fellow of BMJ Case Reports today and you can:

- Submit as many cases as you like

- Enjoy fast sympathetic peer review and rapid publication of accepted articles

- Access all the published articles

Re-use any of the published material for personal use and teaching without further permission

For information on Institutional Fellowships contact consortiasales@bmjgroup.com

Visit casereports.bmj.com for more articles like this and to become a Fellow 